\title{
PENERAPAN DAUROH AL-QUR'AN BAGI SISWI KELAS X DI MADARASAH ALIYAH RAUDHATUL ULUM SAKATIGA INDRALAYA
}

\author{
Komputri Apria Santi \\ Sekolah Tinggi Ilmu Tarbiyah Raudhatul Ulum Sakatiga \\ Email: komputri@stit-ru.ac.id
}

\begin{abstract}
Abstrak
Penelitian ini membahas tentang penerapan dauroh al-Qur'an bagi Siswi Kelas X di Madrasah Aliyah Raudhatul Ulum Sakatiga Indralaya. Dengan tujuan untuk mengetahui sejauh mana penerapan dauroh al-Qur'an bagi Siswi Kelas X di Madrasah Aliyah Raudhatul Ulum Sakatiga Indralaya. Hasil penelitian ini memperlihatkan bahwa Kemampuan membaca al-Qur'an siswa kelas X4 MA Raudhatul Ulum sebelum mengikuti dauroh al-Qur'an tergolong tinggi sebanyak 4 orang $(20 \%)$, tergolong sedang sebanyak 15 orang (75\%) dan yang tergolong rendah sebanyak 1 orang (5\%) atau pada kategori sedang yakni sebanyak 15 orang siswa (75\%) dari 20 siswa. Kemampuan membaca al-Qur'an siswa kelas X4 Madarasah Aliyah Raudhatul Ulum setelah mengikuti dauroh alQur'an yang tergolong tinggi sebanyak 8 orang (20\%), tergolong sedang sebanyak 17 orang (75\%) dan yang tergolong rendah sebanyak 5 orang (5\%), atau pada kategori tinggi yakni sebanyak 8 orang siswa (40\%) dari 20 siswa. Perbedaan kemampuan membaca al-Qur'an siswa Kelas X4 Madarasah Aliyah Raudhatul Ulum Sakatiga Indralaya sebelum dan setelah mengikuti dauroh al-Qur'an dengan diambil df 40 diperoleh ttabel pada taraf signifikansi $5 \%=2,42$ dan ada taraf signifikansi $1 \%=2,02$. Karena " $t 0 "=6,156$ lebih besar dari $t t$, maka hipotesis nihil ditolak dan hipotesis alternatife diterima yaitu ada perbedaan signifikan antara kemampuan membaca kelas X4 MA Raudhatul Ulum sebelum dan setelah mengikuti dauroh al-Qur'an. Dapat disimpulkan bahwa mengajar dengan menggunakan metode dauroh al-Qur'an memberikan peningkatan yang signifikan terhadap kemampuan membaca al-Qur'an siswa kelas X4 MA Raudhatul Ulum Sakatiga.
\end{abstract}

Kata Kunci: -Dauroh Al-Qur'an, Siswi, Madrasah Aliyah

\section{Konsep Pendidikan Islam}

Pendidikan dianggap sebagai suatu investasi yang paling berharga dalam bentuk peningkatan kualitas sumber daya insani untuk pembangunan suatu bangsa. Sering kali kebesaran suatu bangsa diukur dari sejauhmana masyarakatnya mengenyam pendidikan. Semakin tinggi pendidikan yang dimiliki oleh suatu masyarakat, maka semakin majulah bangsa tersebut. Kualitas pendidikan tidak saja dilihat dari kemegahan fasilitas pendidikan yang dimiliki, tetapi sejauhmana output (lulusan) suatu pendidikan dapat membangun sebagai manusia yang paripurna.

Fenomena pendidikan merupakan masalah penting dalam kehidupan,hal ini dikarenakan pendidikan tidak dapat terlepas dari berbagai aktifitas yang terjadi dalam kehidupan.Menurut undang-undang RI Nomor 20 tahun 2003 tentang Sistem Pendidikan Nasional atau Sisdiknas, pasal 1 (ayat 1 dan 4), bahwa "pendidikan 


\section{Penerapan Dauroh Al-Qur'an Bagi Siswi Kelas X di Madrasah Aliyah Raudhatul Ulum Sakatiga Indralaya \\ Komputri Apria Santi}

adalah usaha sadar dan terencana untuk mewujudkan suasana belajar dan proses pembelajaran agar peserta didik secara aktif mengembangkan potensi dirinya untuk memiliki kekuatan spiritual keagamaan, akhlak mulia, pengendalian diri, kecerdasan, keperibadian, serta keterampilan yang diperlukan untuk dirinya, masyarakat, bangsa dan juga negara." (Depag RI: 2006), hlm. 5.

Menurut Kamus Besar Bahasa Indonesia, pendidikan adalah suatu usaha manusia untuk mengubah sikap dan tata laku seseorang atau sekolompok orang dalam usaha mendewasakan manusia melalui upaya pengajaran dan pelatihan (Departemen Pendidikan Nasional, 2013: 326). Pada hakikatnya pendidikan adalah usaha manusia untuk memanusiakan manusia itu sendiri.

Pendidikan merupakan sistem dan cara meningkatkan kualitas hidup manusia dalam segala aspek kehidupan manusia, dalam sejarah umat manusia, hampir tidak ada kelompok manusia yang tidak menggunakan pendidikan sebagai alat pembudayaan dan peningkatan kualitasnya, sekalipun dalam masyarakat terbelakang (primitive) (Hujair, Sanaky, 2003: 4). Begitu pentingnya pendidikan bagi manusia, karena tanpa adanya pendidikan sangat mustahil suatu komunitas manusia dapat hidup berkembang sejalan dengan cita-citanya untuk maju, mengalami perubahan, sejahtera dan bahagia sebagaimana pandangan hidup mereka.Semakin tinggi cita-cita manusia semakin menuntut peningkatan mutu pendidikan sebagaimana pencapainya.

Dasar dan tujuan pendidikan merupakan suatu masalah yang sangat fundamental dalam pelaksanaan pendidikan. Sebab dasar pendidikan itu akan menentukan corak dan isi pendidikan, sedangkan tujuan pendidikan akan menentukan ke arah mana anak didik itu dibawa. Pendidikan merupakan usaha manusia untuk meningkatkan ilmu pengetahuan yang didapat baik dari lembaga formal maupun informal dalam membantu proses transformasi sehingga dapat mencapai kualitas yang diharapkan.

Sebagaimana tujuan Pendidikan Nasional menurut UU No. 20 Tahun 2003 Pasal 3 tentang Sistem Pendidikan Nasional bahwa:

"Pendidikan nasional berfungsi mengembangkan kemampuan dan membentuk watak serta peradaban bangsa yang bermartabat dalam rangka mencerdaskan kehidupan bangsa, bertujuan untuk berkembangnya potensi peserta didik agar menjadi manusia yang beriman dan bertakwa kepada Tuhan Yang Maha Esa, berakhlak mulia, sehat, berilmu, cakap, kreatif, mandiri, dan menjadi warga negara yang demokratis serta bertanggung jawab" (UU Sisdiknas, 2003: 7).

Dasar berbagai pendapat tentang pengertian pendidikan di atas menggambarkan secara umum maupun khusus tentang tujuan pendidkan, yang pada hakekatnya adalah terbentuknya kepribadian bermoral secara utuh yang meliputi aspek spiritual, intelektual, emasional dan fisik serta mengarahkan semua aspek itu kepada kebaikan dan kesempurnaan hidup. 
Volume 4 Nomor 1 Edisi Juni 2019

P-ISSN : 2541-3686

Masaalah mutu pendidikan bukanlah hal yang asing terdengar bagi masayarakat, juga semua telah sepakat bahwa pendidikan dibutuhkan oleh semua orang.Mutu atau kualitas adalah gambaran dan karakteristik menyeluruh dari barang atau jasa yang menunjukkan kemampuannya dalam memuaskan kebutuhan yang diharapkan atau yang tersirat. Dalam konteks pendidikan, pengertian mutu mencakup input, proses, dan output pendidikan (Rohita, 2010: 52).

Jadi pendidikan yang bermutu adalah pendidikan yang mengacu pada berbagai input seperti tenaga pengajar, peralatan, buku, biaya pendidikan, teknologi, dan input-input lainnya yang diperlukan dalam proses pendidikan. Ada pula yang mengaitkan mutu pada proses (pembelajaran), dengan argumen bahwa proses pendidikan (pembelajaran) yang paling menentukan adalah kualitas. Orientasi mutu dari aspek output mendasarkan pada hasil pendidikan yang ditujukan oleh keunggulan akademik dan nonakademik di suatu sekolah.

Mutu Pendidikan di sekolah dapat diartikan sebagai kemampuan sekolah dalam pengelolaan secara operasional dan efisien terhadap komponen-komponen yang berkaitan dengan sekolah, sehingga menghasilkan nilai tambah terhadap komponen tersebut menurut norma atau standar yang berlaku.

Beberapa penerapan pola peningkatan mutu di Indonesia telah banyak dilakukan, namun masih belum dapat secara langsung memberikan efek perbaikan mutu. Diantaranya adalah usaha peningkatan mutu dengan perubahan kurikulum dan proyek peningkatan lain.Dalam konteks pendidikan, produk dari lembaga pendidikan berupa jasa.Kepuasan pelanggan (siswa, orang tua, dan masyarakat) dibagi dalam dua aspek yaitu tata layanan pendidikan dan prestasi yang dicapai siswa.

Masalah yang terjadi dalam dunia pendidikan sangatlah rumit, baik yang berhubungan dengan kurikulum, kegiatan belajar mengajar (KBM), fasilitas pendidikan, guru dan peserta didik.Oleh karena itu, semua struktur sekolah terutama guru harus ekstra sabar dan mau bekerja lebih ekstra untuk meluangkan waktunya dalam meningkatkan prestasi siswa dan mencapai tujuan mutu pendidikan tersebut.

Di dalam kelas, seorang guru pasti akan menemukan aneka tingkah dan persoalan yang dihadapi anak didiknya. Ada yang sangat rajin belajar, ada yang biasa-biasa saja, dan ada yang sama sekali tidak mau belajar. Dalam hal ini, guru harus berperan sebagai seorang motivator bagi anak didiknya yang malas belajar, dan dauroh al-Qura'an dapat membantu untuk meningkatkan motivasi belajar siswa.Istilah dauroh yang dimaksud oleh peniliti disini ialah pelatihan.Istilah pelatihan al-Qur'an ini telah mashur dengan istilah dauroh al-Qur'an dikalangan warga pesantren Raudhatul Ulum.

Menurut Budi Santoso, pelatihan dilakukan untuk meningkatkan pengetahuan, keterampilan, kinerja, dan perilaku individual, kelompok maupun organisasi. Oleh karena itu kegiatan pelatihan harus dirancang sedemikian rupa agar benar-benar memberikan manfaat sesuai dengan tujuan pelaksanaaya (Santoso, 2010: 1). Dan 


\section{Penerapan Dauroh Al-Qur'an Bagi Siswi Kelas X di Madrasah Aliyah Raudhatul Ulum \\ Sakatiga Indralaya \\ Komputri Apria Santi}

tujuan pelatihan yaitu agar peserta pelatihan baik kelompok atau organisasi maupun perseorangan dapat mengusai pengetahuan, keterampilan dan prilaku yang dilatihkan dalam program pelatihan sehingga dapat diaplikasikan baik untuk jangka waktu pendek maupun jangka waktu yang lama (Santoso, 2010: 1).

Dalam belajar masih diperlukan pengulangan. Pengulangan sangat diperlukan dalam mendukung proses mengingat. Mengingat merupakan salah satu proses yag cukup sulit, sehingga diperlukan suatu cara khusus untuk dapat melakukan kegiatan tersebut. Hal-hal yang telah dipelajari terkadang sulit untuk dimunculkan kembali atau bahka tidak diproduksi lagi dalam daya ingat kita, maka ini dinamakan lupa.

Pengulangan beberapa kali dalam belajar dapat membantu proses pemahaman yang mendalam dan mengatasi lupa, selain itu pengulangan diharapkan dapat mengoptimalkan hasil belajar siswa. Penguasaan secara penuh dari setiap langkah memungkinkan belajar secara keseluruhan lebih berarti, maka pengulangan masih diperlukan dalam kegiatan pembelajaran.

Madrasah ini telah banyak mengeluarkan alumni-alumninya, baik dalam negeri maupun luar negeri. Dalam hal ini dauroh al-Qur'an sangat membantu dalam membangun pendidikan peserta didik di madrasah ini, terutama alumni yang melanjutkan keluar negeri seperti Madinah, Mesir, Yaman, Yordaniah, Turkey, Syiria, dan Sudan. Dalam hal ini dauroh al-Qur'an sangat berperan dalam pendidikan alumni-alumninya, karena selain bisa membaca al-Qur'an dengan baik dan menghafal al-Qur'an, dauroh al-Qur'an juga berperan penting dalam bahasa Arab, baik dalam bahasa Arab, baik dalam pelajaran yang menggunakan bahasa Arab maupunn dalam pengucapan berbahasa Arab.

\section{Metode Penelitian}

Metode penelitian adalah cara-cara yang dapat digunakan oleh peneliti untuk mengumpulkan data (Arikunto, 2010: 100). Sedangkan menurut Beni Ahmad Saebani, metode penelitian adalah metode yang digunakan dalam aktivitas penelitian (Saebani, 2008: 43). Dalam hal ini, data-data penelitian ini dikumpulkan dengan metode tes, metode observasi, dokumentasi. Di bawah ini peneliti akan menjelaskan metode-metode yang akan peneliti pergunakan.

1. Jenis Penelitian

Ditinjau dari pendekatannya, penelitian ini adalah termasuk jenis penelitian kuantitatif (Sebab, mencoba menguak data dalam bentuk angka-angka statistik, dan sebagainya) (Sugiyono, 2013: 9). Dari sisi desainnya penelitian ini menggunakan desain pre dan post test (maksudnya adalah dalam penelitian yang dilakukan ada pretest sebelum perlakuan. Dengan demikian hasil perlakuan dapat lebih akurat, karena dapat membandingkan dengan keadaan sebelum diberi perlakuan. Desain ini dapat digambarkan seperti pada gambar 1 di bawah ini) (Sugiyono, 2013: 9). Penelitian ini bertujuan menguji coba suatu metode pembelajaran. Maksudnya, 
Volume 4 Nomor 1 Edisi Juni 2019

P-ISSN : 2541-3686

mengenai penerapan dauroh al-Qur'an pada kelas $X^{4}$ di MA Raudhatul Ulum. Untuk lebih jelasnya dapat dilihat pada desain di bawah ini (Amzir, 2014: 97):

Gambar 1

Desain Penelitian

One group pretest posttest study

$0_{1} \quad \mathrm{X}_{2}$

Keterangan:

$$
\begin{aligned}
& X=\text { perlakuan } \\
& 0_{1}=\text { pretest } \\
& 0_{2}=\text { posttest }
\end{aligned}
$$

2. Teknik pengumpulan data

Sesuai dengan penelitain yang menggunakan kualitatif, maka metode dalam pengumpulan data dilakukan melalui teknik observasi, wawancara dan dokumentasi.

a. Metode Tes

Tes sebagai alat penilaian adalah pertanyaan-pertanyaan yang diberikan kepada siswa untuk mendapat jawaban dari siswa dalam bentuk tulisan (Sudijono, 2011: 76). Tes yang digunakan berupa tes membaca al-Qur'an. Tes digunakan untuk menguji tingkat kemampuan membaca al-Qur'an kelas $\mathrm{X}^{4} \mathrm{MA}$ Raudhatul Ulum. Maka peneliti perlu mengadakan tes terhadap sampel.

b. Metode Dokumentasi

Metode ini digunakan untuk memperoleh catatan, transkrip, buku, surat kabar, data dan sebagainya (Arikunto,. 2006: 274). Jadi metode ini, adalah metode pengumpulan data dengan cara mencari informasi, melalui dokumentasi, arsiparsip, buku-buku catatan dan lainnya terkait dengan data yang dibutuhkan. Metode dokumentasi ini dilakukan sebagai bahan banding untuk mendukung atau meningkatkan kepercayaan hasil data yang dikumpulkan melalui metode observasi tentang Penerapan Dauroh Al-Qur'an Bagi Siswi Kelas X ${ }^{4}$ di Madarasah Aliyah Raudhatul Ulum Sakatiga Indralaya.

3. Validitas dan Reabilitas Instrumen

a. Validitas Instrument

Suatu instrument yang baik haruslah valid dan reliable yaitu instrumen kemampuan membaca al-Qur'an siswa kelas $X^{4}$ MA Raudhatul Ulum. validitas instrument adalah tingkatan dimana instrument mengukur apa yang seharusnya diukur. Dari pendapat di atas, dapat dikatakan bahwa instrument yang valid adalah instrumen yang mampu mengukur apa yang seharusnya diukur atau yang diinginkan. Suatu instrument dapat dikatakan memiliki validitas yang tinggi apabila butir-butir yang membentuk instrument tidak menyimpang dari fungsi instrument tersebut dan faktor-faktor yang merupakan bagian dari instrument tersebut tidak menyimpang dari fungsi instrument (Arikunto, 2006: 172). 
Untuk memenuhi validitas tersebut, maka instrumen tes yang dikembangkan untuk penelitian ini dilakukan validasi dengan cara sebagai berikut:

1) Instrumen tersebut disusun berdasarkan teori dauroh al-Qur'an;

2) Instrumen tersebut disusun menggunakan kisi-kisi, indikator dan item-item yang dijabarkan dari indikator;

3) Instrumen tersebut diujicobakan kepada 20 sampel yang terdapat dalam populasim (Sugiyono, 2013: 352). Dengan rumus korelasi product moment berikut (Ancok, 2009: 137):

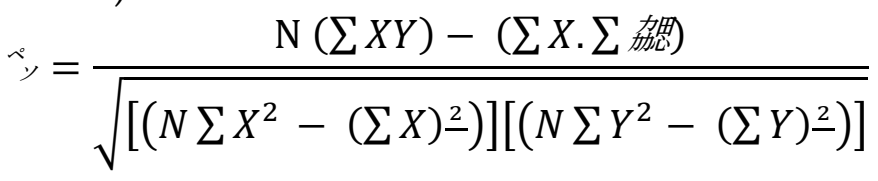

Keterangan:

$\mathrm{N} \quad$ : jumlah sampel

$\mathrm{X} \quad$ : jumlah skor pertanyaan

Y : jumlah skor total

r : nilai setiap butir

Apabila nilai $\mathrm{r}$ dikonsultasikan tabel $\mathrm{r}$ ( $\mathrm{r}_{\text {tabel }}$ ) dan ternyata nilai $\mathrm{r}$ lebih kecil maka nilai $r$ tersebut tidak signifikan atau butir tersebut harus diganti atau dibuang.

b. Reliabilitas Instrumen

Reliabilitas adalah kemampuan suatu alat ukur apabila digunakan kepada beberapa kali pengukuran tidak akan mengalami perubahan. Reliabilitas suatu tes adalah kemampuan suatu alat ukur untuk digunakan dalam tingkatan yang sama untuk beberapa kali.

Dari beberapa pendapat itu dapat disimpulkan bahwa reliabilitas adalah suatu kemantapan alat ukur atau instrument apabila digunakan sebagai alat ukur. Artinya sampel manapun dapat diukur dengan alat atau instrument tersebut. Suatu alat ukur atau instrument yang reliable adalah alat ukur atau instrument yang memberikan hasil yang mantap walaupun dipakai berkali-kali (Suharno, 1984: 20). Untuk mendapatkan reliabilitas yang tinggi maka instrument angket kemampuan membaca al-Qur'an siswa diuji dengan menggunakan rumus Spearman-Brown (teknik belah dua) berikut ini (Nurgiyantoro, dkk, 2002: 324)

$$
r_{1}=\frac{2 r_{\mathrm{gg}}}{1+r_{\mathrm{gg}}}
$$

$\mathrm{r}_{1}=$ reabilitas internal

$\mathrm{r}_{\mathrm{gg}}=$ korelasi product moment antara belahan ganjil dan genap

Koefisien korelasi yang telah diperoleh dikonsultasikan dengan tabel $\mathrm{r}$ product moment, apabila harga $\mathrm{r}_{1}$ lebih besar dari $\mathrm{r}$ dalam tabel pada taraf signifikan $5 \%$, maka instrument tersebut dapat disebut instrument yang reliabel.

4. Teknik Analisis Data 
Untuk mengetahui kemampuan membaca al-Qur'an siswa Kelas $X^{4}$ Madarasah Aliyah Raudhatul Ulum Sakatiga Indralaya dilakukan uji hipotesis. Berdasarkan hipotesis yang dirumuskan maka rumusan hipotesis statistik dalam penelitian ini adalah sebagai berikut:

Data instrumen tes yang digunakan untuk menjawab rumusan masalah pertama dan kedua akan di analisis dengan teknik statistic uji TSR (tinggi, sedang dan rendah). Untuk mengetahui bagaimana perbedaan kemampuan membaca alQur'an siswa Kelas X'Madarasah Aliyah Raudhatul Ulum Sakatiga Indralaya sebelum dan setelah mengikuti dauroh al-Qur'an, maka menggunakan rumus statistik yakni uji T. Rumus uji T yang dimaksudsebagai berikut:

Keterangan:

$M_{1}$ danM2 $\quad$ : Rata Rata sebelum perlakuan dan setelah perlakuan

$S E_{M 1} d a n S E_{M 2} \quad$ : Standar Error sebelum perlakuan dan setelah perlakuan ${ }^{1}$

\section{Hasil Pembahasan}

\section{Penerapan Dauroh al-Qur'an Siswa Kelas X di MA Raudhatul Ulum}

Variabel yang diteliti adalah kemampuan membaca al-Qur'an pada siswa $X^{4}$. Kegiatan pra eksperimen dalam penelitian ini adalah hasil tes membaca al-Qur'an siswa kelas $\mathrm{X}^{4}$ pada mengikuti tes masuk di MA Raudhatu Ulum Sakatiga. Sedangkan post eksperimen adalah hasil tes kemampuan membaca al-Qur'an siswa kelas $X^{4}$ pada saat ujian membaca al-Qur'an semester ganjil tahun ajaran 2016-2017 dalam artian telah mendapat perlakuan pembelajaran al-Qur'an dengan metode dauroh al-Qur'an.

Pada awal penelitian terlebih dahulu peneliti mengujicobakan instrument penelitian di kelas X MA Raudhatul Ulum berupa 20 item pertanyaan. Adapun instrumen ini yang akan dipergunakan peneliti sebagai soal yang akan diberikan sebagai pretest dan posttest. Setelah melihat hasil observasi tersebut ternyata penerapan dauroh al-Qur'anerat kaitannya dengan peningkatan kemampuan membaca al-Qur'an siswa kelas $X^{4}$ di MA Raudhatul Ulum.

Sebelum instrumen diberikan kepada kelas yang diteliti, terlebih dahulu diujicobakan pada kelas uji coba agar diperoleh butir soal yang valid, reabil dan bisa digunakan untuk penelitian.

\section{a. Uji validitas hasil belajar}

Hasil analisis pada variabel kemampuan membaca al-Qur'an dengan sampel 21 siswa dan jumlah pertanyaan sebanyak 20 soal dengan nilai $r$ tabel $=0,444$. Setelah dianalisis dengan menggunakan program SPSS versi 22, semua butir

\footnotetext{
${ }^{1}$ Ibid., hal. 346
} 
Penerapan Dauroh Al-Qur'an Bagi Siswi Kelas X di Madrasah Aliyah Raudhatul Ulum

Sakatiga Indralaya

Komputri Apria Santi

pertanyaan yang diajukan dapat dinyatakan valid. Lebih jelas dapat dilihat pada tabel di bawah ini:

Tabel

Hasil Uji Validitas Soal

\begin{tabular}{|c|c|c|c|}
\hline No. Item & $\begin{array}{c}\text { Nilai r tabel } \\
(\mathbf{n}=\mathbf{2 0})\end{array}$ & $\begin{array}{c}\text { Nilai } \\
\text { koefisien } \\
\text { Korelasi }\end{array}$ & Keterangan \\
\hline Butir 1 & 0,444 & 0,806 & Valid \\
\hline Butir 2 & 0,444 & 0,488 & Valid \\
\hline Butir 3 & 0,444 & 0,453 & Valid \\
\hline Butir 4 & 0,444 & 0,806 & Valid \\
\hline Butir 5 & 0,444 & 0,466 & Valid \\
\hline Butir 6 & 0,444 & 0,466 & Valid \\
\hline Butir 7 & 0,444 & 0,488 & Valid \\
\hline Butir 8 & 0,444 & 0,453 & Valid \\
\hline Butir 9 & 0,444 & 0,492 & Valid \\
\hline Butir 10 & 0,444 & 0,466 & Valid \\
\hline Butir 11 & 0,444 & 0,806 & Valid \\
\hline Butir 12 & 0,444 & 0,467 & Valid \\
\hline Butir 13 & 0,444 & 0,653 & Valid \\
\hline Butir 14 & 0,444 & 0,628 & Valid \\
\hline Butir 15 & 0,444 & 0,492 & Valid \\
\hline Butir 16 & 0,444 & 0,479 & Valid \\
\hline Butir 17 & 0,444 & 0,488 & Valid \\
\hline Butir 18 & 0,444 & 0,628 & Valid \\
\hline Butir 19 & 0,444 & 0,653 & Valid \\
\hline Butir 20 & 0,444 & 0,806 & Valid \\
\hline
\end{tabular}

Sumber: Data primer yang diolah

Dari data di atas dapat diketahui sebanyak 20 butir butir pertanyaan pada nilai koefisien korelasi $>0,444$ ( rhitung $>\mathrm{r}_{\text {tabel}}$ ) dinyatakan valid. Dengan demikian semua butir pada tes kemampuan membaca al-Qur'an siswa $X^{4}$ dinyatakan valid dan dipakai dalam penelitian.

b. Uji Reliabilitas

Berdasarkan hasil uji reliabilitas dengan menggunakan rumus Cronbach Alpha untuk variabel kemampuan membaca al-Qur'an menunjukkan bahwa nilai Alpha di atas $0,6(\alpha \geq 0,6)$, maka instrumen tersebut dapat dinyatakan reliabel.

\section{Tabel}


RAUDHAH Proud To Be Professionals Jurnal Tarbiyaholamiyah

Volume 4 Nomor 1 Edisi Juni 2019

P-ISSN : 2541-3686

Hasil Uji Reliabilitas

\begin{tabular}{|c|c|c|c|}
\hline No. & Variabel & $\begin{array}{c}\text { Nilai Koefisien } \\
\text { Cronbach Alpha }\end{array}$ & Keterangan \\
\hline 1. & $\begin{array}{c}\text { Kemampuan } \\
\text { Membaca al- } \\
\text { Qur'an }\end{array}$ & 0,962 & Reliabel \\
\hline
\end{tabular}

Sumber: Data primer yang diolah

2. Kemampuan Membaca Al-Qur'an Siswi Kelas $X^{4}$ MA Raudhatul Ulum Sakatiga Indralaya Sebelum Mengikuti Dauroh Al-Qur'an

Pada bagian ini disajikan data yang terkumpul dari soal tes saat siswa mengikuti tes masuk yaitu tes membaca al-Qur'an yang telah diberikan sebagai hasil pre test, maka diperoleh data sebagai berikut:

Tabel

Nilai Kemampuan Membaca al-Qur'an Siswa Kelas $X^{4}$ (Pre-Test)

\begin{tabular}{|c|l|c|}
\hline No & \multicolumn{1}{|c|}{ Nama Siswa $\mathbf{X}^{4}$} & Nilai \\
\hline 1. & Abdul Aziz & 60 \\
\hline 2. & Andrian Aswanto & 65 \\
\hline 3. & Ahlun Naza & 70 \\
\hline 4. & Angga Setia Tama & 60 \\
\hline 5. & Bondan. W. R & 60 \\
\hline 6. & Dwi Suryadi & 65 \\
\hline 7. & Eko Prasetio & 80 \\
\hline 8. & Elvan Saputra & 60 \\
\hline 9. & Fajri & 65 \\
\hline 10. & Felli Wahyu Pangestu & 70 \\
\hline 11. & Gunawan & 60 \\
\hline 12. & Hernando & 65 \\
\hline 13. & Ical Asmanda & 60 \\
\hline 14. & Ihsan Raihan & 65 \\
\hline 15. & Jefrianto & 65 \\
\hline 16. & M. Marzani & 60 \\
\hline 17. & M. Nur & 75 \\
\hline 18. & M. Sudarmanto & 65 \\
\hline 19. & Nanang Priyanto & 60 \\
\hline 20. & Rami Ariadi & 55 \\
\hline & & \\
\hline
\end{tabular}


Penerapan Dauroh Al-Qur'an Bagi Siswi Kelas X di Madrasah Aliyah Raudhatul Ulum

Sakatiga Indralaya

Komputri Apria Santi

Dari tabel di atas dapat diketahui bahwa siswa yang mendapat nilai di atas 60 ada 19 orang (95\%) dan di bawah 60 ada 1 orang (5\%) yakni nilai 80 ada 1 orang (5\%), 75 ada 1 orang (5\%), 70 ada 2 orang (10\%), 65 ada 7 orang (35\%), 60 ada 8 orang $(40 \%)$ dan 55 ada 1 orang (5\%).

Dari hasil tes secara langsung yang di berikan pada siswa, didapat data tentang kemampuan membaca al-Qur'an siswa sebelum diterapkan dauroh al-Qur'an. Setelah data-data terkumpul, maka proses pengelolaan data dilakukan sebagai berikut:

a. Peneliti melakukan penskoran kedalam tabel frekuensi

Tabel

\section{Distribusi Nilai Hasil Pre-Test}

\begin{tabular}{|c|c|c|c|c|c|c|}
\hline No & $\mathbf{X}$ & $\mathbf{F}$ & $\mathbf{f X}$ & $\mathbf{X}(\mathbf{X}-\mathbf{M x})$ & $\mathbf{x}^{\mathbf{2}}$ & $\mathbf{f x}^{\mathbf{2}}$ \\
\hline 1 & 80 & 1 & 80 & 16 & 256 & 256 \\
\hline 2 & 75 & 1 & 75 & 9 & 81 & 81 \\
\hline 3 & 70 & 2 & 140 & 6 & 36 & 72 \\
\hline 4 & 65 & 7 & 455 & 1 & 1 & 8 \\
\hline 5 & 60 & 8 & 480 & -4 & 16 & 128 \\
\hline 6 & 55 & 1 & 55 & -9 & 81 & 81 \\
\hline \multicolumn{2}{|c|}{ Total } & $\mathrm{N}=20$ & $\sum \mathrm{fx}=1285$ & & & $\sum \mathrm{fx}^{2}=626$ \\
\hline
\end{tabular}

b. Mencari Nilai Rata-Rata

$$
\begin{aligned}
M_{I} & =\frac{\sum f X}{N} \\
& =\frac{1285}{20} \\
= & 64,25 \text { dibulatkan } 64
\end{aligned}
$$

c. Mencari $\mathrm{SD}_{1}$

$$
\begin{aligned}
S D_{1} & =\sqrt{\frac{\sum f x^{2}}{N}} \\
& =\sqrt{\frac{626}{20}} \\
& =\sqrt{31,3} \\
& =5,59 \text { dibulatkan } 6
\end{aligned}
$$

d. Mengelompokkan hasil belajar ke dalam tiga kelompok yaitu tinggi, sedang, rendah (TSR)(Sudijono, 2008: 176-178):

$\begin{array}{ll}\stackrel{\mathrm{M}+1 \mathrm{SD}}{\mathrm{Nilai} \text { M-1 SD s.d. } \mathrm{M}+1 \mathrm{SD}} & \text { Tinggi } \\ {\text { Sedang }}\end{array}$




$$
\mathrm{M}-1 \mathrm{SD} \longrightarrow \text { Rendah }
$$

Lebih lanjut penghitungan pengkategorian TSR dapat dilihat pada skala dibawah ini:

$\begin{array}{ll}64+6=70 & \begin{array}{l}\text { Hasil belajar siswa sebelum digunakan } \\ \text { dauroh al-Qur'an dikategorikan tinggi }\end{array} \\ \text { Nilai 59 s.d. } 69 & \begin{array}{l}\text { Hasil belajar siswa sebelum digunakan } \\ \text { dauroh al-Qur'an dikategorikan sedang }\end{array} \\ 64-6=58 & \begin{array}{l}\text { Hasil belajar siswa sebelum digunakan } \\ \text { dauroh al-Qur'an dikategorikan rendah }\end{array}\end{array}$

Tabel

Persentase Nilai Hasil Pre-Test Kelas Kelas X ${ }^{4}$

\begin{tabular}{|l|l|c|c|}
\hline No & \multicolumn{1}{|c|}{ Kategori } & Frekuensi & Persentase \\
\hline 1. & Tinggi & 4 & $20 \%$ \\
2. & Sedang & 15 & $75 \%$ \\
3. & Rendah & 1 & $5 \%$ \\
\hline \multicolumn{2}{|c|}{ JUMLAH } & 20 & $100 \%$ \\
\hline
\end{tabular}

Berdasarkan tabel diatas dapat diketahui bahwa kemampuan membaca alQur'an siswa kelas $X^{4}$ sebelum diterapkan dauroh al-Qur'an yang tergolong tinggi (baik) sebanyak 4 orang siswa (20\%), tergolong sedang sebanyak 15 orang siswa (75 $\%)$ dan yang tergolong rendah sebanyak 1 orang siswa (5\%). Dengan demikian hasil pre test pada kelas $\mathrm{X}^{4}$ pada kategori sedang yakni sebanyak 15 orang siswa $(75 \%)$ dari 20 siswa yang menjadi sampel penelitian ini.

\section{Kemampuan Membaca Al-Qur'an Siswi Kelas $X^{4}$ Madarasah Aliyah Raudhatul} Ulum Sakatiga Indralaya Setelah Mengikuti Dauroh Al-Qur'an

Pada bagian ini disajikan data yang terkumpul dari soal tes saat siswa mengikuti ujian semester ganjil yaitu ujian membaca al-Qur'an yang telah mengikuti metode dauroh al-Qur'an dandijadikan sebagai hasil post test, maka diperoleh data sebagai berikut:

a. Kemampuan Membaca Al-Qur'an Siswi Kelas $X^{4}$ Setelah Mengikuti metode Dauroh Al-Qur'an

Tabel Nilai Kemampuan Membaca al-Qur'an Siswa Kelas $\mathrm{X}^{4}$ (Post-Test)

\begin{tabular}{|c|l|c|}
\hline No & \multicolumn{1}{|c|}{ Nama Siswa $\mathbf{X}^{\mathbf{4}}$} & Nilai \\
\hline 1. & Abdul Aziz & 90 \\
\hline 2. & Andrian Aswanto & 75 \\
\hline 3. & Ahlun Naza & 95 \\
\hline
\end{tabular}


Penerapan Dauroh Al-Qur'an Bagi Siswi Kelas X di Madrasah Aliyah Raudhatul Ulum Sakatiga Indralaya Komputri Apria Santi

\begin{tabular}{|c|l|c|}
\hline 4. & Angga Setia Tama & 65 \\
\hline 5. & Bondan. W. R & 80 \\
\hline 6. & Dwi Suryadi & 85 \\
\hline 7. & Eko Prasetio & 95 \\
\hline 8. & Elvan Saputra & 80 \\
\hline 9. & Fajri & 70 \\
\hline 10. & Felli Wahyu Pangestu & 85 \\
\hline 11. & Gunawan & 85 \\
\hline 12. & Hernando & 70 \\
\hline 13. & Ical Asmanda & 95 \\
\hline 14. & Ihsan Raihan & 75 \\
\hline 15. & Jefrianto & 65 \\
\hline 16. & M. Marzani & 80 \\
\hline 17. & M. Nur & 90 \\
\hline 18. & M. Sudarmanto & 75 \\
\hline 19. & Nanang Priyanto & 80 \\
\hline 20. & Rami Ariadi & 90 \\
\hline
\end{tabular}

Dari tabel di atas dapat diketahui bahwa siswa yang mendapat nilai di atas 60 ada 20 orang (100\%) dan di bawah 60 tidak ada yakni nilai 95 ada 3 orang (15\%), 90 ada 3 orang (15\%), 85 ada 2 orang (10\%), 80 ada 4 orang (20\%), 75 ada 3 orang (15\%), 70 ada 2 orang (10\%) dan 65 ada 3 orang (15\%).

Dari hasil tes secara langsung yang di berikan pada siswa, didapat data tentang kemampuan membaca al-Qur'an siswa setelah diterapkan dauroh al-Qur'an. Setelah data-data terkumpul, maka proses pengelolaan data dilakukan sebagai berikut:

a. Peneliti melakukan penskoran kedalam tabel frekuensi

Tabel

Distribusi Nilai Hasil Post-Test

\begin{tabular}{|c|c|c|c|c|c|c|}
\hline No & $\mathbf{X}$ & $\mathbf{F}$ & $\mathbf{f X}$ & $\begin{array}{c}\mathbf{X} \\
(\mathbf{X}-\mathbf{M x})\end{array}$ & $\mathbf{X}^{\mathbf{2}}$ & $\mathbf{f x}^{\mathbf{2}}$ \\
\hline 1 & 95 & 3 & 295 & 14 & 196 & 588 \\
\hline 2 & 90 & 3 & 270 & 9 & 81 & 243 \\
\hline 3 & 85 & 2 & 170 & 4 & 16 & 32 \\
\hline 4 & 80 & 4 & 320 & -1 & 1 & 4 \\
\hline 5 & 75 & 3 & 225 & -6 & 36 & 108 \\
\hline
\end{tabular}


RAUDHAH Proud To Be Professionals Jurnal Tarbiyah)damiyah

Volume 4 Nomor 1 Edisi Juni 2019

P-ISSN : 2541-3686

\begin{tabular}{|c|c|c|c|c|c|c|}
\hline 6 & 70 & 2 & 140 & -11 & 121 & 242 \\
\hline 7 & 65 & 3 & 195 & 16 & 256 & 768 \\
\hline \multicolumn{2}{|c|}{ Total } & $\mathrm{N}=20$ & $\sum \mathrm{fx}=1615$ & & & $\sum \mathrm{fx}^{2}=1985$ \\
\hline
\end{tabular}

b. Mencari Nilai Rata-Rata

$$
\begin{aligned}
M_{I} & =\frac{\sum f X}{N} \\
= & \frac{1615}{20} \\
& =80,75 \text { dibulatkan } 81
\end{aligned}
$$

c. Mencari $\mathrm{SD}_{1}$

$$
\begin{aligned}
S D_{1} & =\sqrt{\frac{\sum f x^{2}}{N}} \\
& =\sqrt{\frac{1985}{20}} \\
& =\sqrt{99,25} \\
& =9,96 \text { dibulatkan } 10
\end{aligned}
$$

\begin{tabular}{|c|c|}
\hline $\mathrm{M}+1 \mathrm{SD}$ & Tinggi \\
\hline Nilai M-1 SD s.d. M+1 SD & Sedang \\
\hline$M-1 S D$ & \\
\hline
\end{tabular}

d. Mengelompokkan hasil belajar ke dalam tiga kelompok yaitu tinggi, sedang, rendah (TSR) (Sudijono, 2008: 175-176):

Lebih lanjut penghitungan pengkategorian TSR dapat dilihat pada skala dibawah ini:

$81+10=91 \longrightarrow \begin{aligned} & \text { Hasil belajar siswa sebelum digunakan } \\ & \text { dauroh al-Qur'an dikategorikan tinggi }\end{aligned}$
Nilai 72 s.d.90 $\longrightarrow \quad \begin{aligned} & \text { Hasil belajar siswa sebelum digunakan } \\ & \text { dauroh al-Qur'an dikategorikan sedang }\end{aligned}$
$\begin{aligned} & \text { Hasil belajar siswa sebelum digunakan } \\ & \text { dauroh al-Qur'an dikategorikan rendah }\end{aligned}$

Tabel

Persentase Nilai Hasil Post-Test Kelas Kelas $\mathrm{X}^{4}$

\begin{tabular}{|l|l|l|l|}
\hline No & Kategori & Frekuensi & Persentase \\
\hline
\end{tabular}




\begin{tabular}{|l|l|l|l|}
\hline 1. & Tinggi & 8 & $40 \%$ \\
2. & Sedang & 7 & $35 \%$ \\
3. & Rendah & 5 & $25 \%$ \\
\hline \multicolumn{2}{|r|}{ JUMLAH } & 20 & $100 \%$ \\
\hline
\end{tabular}

Berdasarkan tabel diatas dapat diketahui bahwa kemampuan membaca alQur'an siswa kelas $X^{4}$ setelah diterapkan dauroh al-Qur'an yang tergolong tinggi (baik) sebanyak 8 orang siswa (20\%), tergolong sedang sebanyak 17 orang siswa (75 $\%$ ) dan yang tergolong rendah sebanyak 5 orang siswa (5\%). Dengan demikian hasil pre test pada kelas $X^{4}$ pada kategori tinggi yakni sebanyak 8 orang siswa (40\%) dari 20 siswa yang menjadi sampel penelitian ini.

\section{Perbedaan Kemampuan Membaca al-Qur'an Siswi Kelas $X^{4}$ Madarasah Aliyah} Raudhatul Ulum Sakatiga Indralaya Sebelum dan Setelah Mengikuti Dauroh al-Qur'an

Pada bab ini merupakan bab analisis data yang berisikan beberapa masalah yang diangkat dalam penelitian ini antara lain penggunaan tes " $\mathrm{t}$ " untuk menguji dua sampel kecil dengan penggunaan dauroh al-Qur'an terhadap kemampuan membaca al-Qur'an siswa kelas $X^{4}$ di MA Raudhatul Ulum.

Penggunaan tes " $\mathrm{t}$ " pada penelitian ini mengasumsikan hipotesis untuk mengetahui apakah terdapat perbedaan kemampuan membaca al-Qur'an yang signifikan pada siswa kelas $\mathrm{X}^{4}$ sebelum dan setelah mengikuti dauroh al-Qur'an. Apabila nilai $t_{0}$ yang diperoleh lebih besar daripada " $\mathrm{t}$ " tabel maka hipotesis Nihil yang diajukan ditolak. Suatu kegiatan penelitian eksperimental, telah berhasil menemukan penggunaan dauroh al-Qur'an sebagai perantara yang baik untuk meningkatkan kemampuan membaca al-Qur'an siswa kelas $X^{4}$ di MA Raudhatul Ulum. Dalam rangka uji coba efektivitas atau keampuhan penggunaan dauroh alQur'an ini, dilaksanakan penelitian lanjutan, dengan mengajukan Hipotesis Nihil: ada pengaruh atau tidak ada pengaruh yang signifikan antara penggunaan dauroh al-Qur'an terhadap kemampuan membaca al-Qur'an siswa kelas $X^{4}$ di $\mathrm{MA}$ Raudhatul Ulum.Perbedaan kemampuan membaca al-Qur'an siswa Kelas $X^{4}$ sebelum dan setelah mengikuti metode Dauroh al-Qur'an.

$$
\begin{array}{lll}
\text { Untuk menguji hipotesis tersebut } & \multicolumn{2}{c}{\text { digunakan }} \\
& \multicolumn{3}{c}{t_{0}=\frac{M_{1}-M_{2}}{S E_{M_{1}-M_{2}}}} & \\
& & \mathrm{~N}_{1}=20 \\
\mathrm{M}_{1}=81 & \mathrm{SD}_{1}=10 & \mathrm{~N}_{2}=20 \\
\mathrm{M}_{2}=64 & \mathrm{SD}_{2}=6 &
\end{array}
$$


RAUDHAH Proud To Be Professionals Jurnal Tarbiyaholamiyah

Volume 4 Nomor 1 Edisi Juni 2019

P-ISSN : 2541-3686

$$
\begin{aligned}
S E_{M_{1}}=\frac{S D_{1}}{\sqrt{N_{1}-1}} & \\
= & \frac{6}{\sqrt{20-1}} \\
& =\frac{6}{\sqrt{19}} \\
& =\frac{6}{4,35} \\
& =1,379 \\
S E_{M_{2}}= & \frac{S D_{2}}{\sqrt{N_{2}-1}} \\
= & \frac{10}{\sqrt{20-1}} \\
= & \frac{10}{\sqrt{19}} \\
= &
\end{aligned}
$$

a) Menentukan Standard Error perbedaan Mean Variabel I dan Mean Variabel II, dengan rumus :

$$
\begin{aligned}
& S E_{M_{1}-M_{2}}=\sqrt{S E_{M_{1}}{ }^{2}+S E_{M_{2}}{ }^{2}}=\sqrt{(1.379)^{2}+(2,298)^{2}} \\
& =\sqrt{1,901641+5,280804}=\sqrt{7,182445} \\
& =2,680
\end{aligned}
$$

b) Mencari " $\mathrm{t}$ " atau $\mathrm{t}_{0}$ :

$$
t_{0}=\frac{M_{1}-M_{2}}{S E_{M_{1}-M_{2}}}=\frac{80,75-64,25}{2,680}=\frac{16,50}{2,680}=6,156
$$

c) Memberikan interpretasi

df atau $\mathrm{db}=(N 1+N 2-2)=20+20-2=38$

dengan df sebesar 38 tidak ditemui, maka diambil df 40 diperoleh tabel sebagai berikut:

- Pada taraf signifikansi $5 \%=2,42$

- Pada taraf signifikansi $1 \%=2,02$

Karena " $\mathrm{t}_{0}$ " = 6,156 lebih besar dari $\mathrm{t}_{\mathrm{t}}$ (baik pada taraf signifikansi $5 \%$ dan $1 \%$ ), maka hipotesis nihil ditolak dan hipotesis alternative diterima. Berarti ada perbedaan signifikan antara kemampuan membaca kelas $X^{4}$ MA Raudhatul Ulum sebelum dan setelah mengikuti dauroh al-Qur'an. Dapat disimpulkan bahwa penggunaan metode dauroh al-Qur'an memberikan peningkatan yang signifikan terhadap kemampuan membaca al-Qur'an siswa kelas $X^{4}$ MA Raudhatul Ulum Sakatiga.

\section{Simpulan}


1. Kemampuan membaca al-Qur'an siswa kelas $X^{4}$ MA Raudhatul Ulum sebelum mengikuti dauroh al-Qur'an tergolong tinggi sebanyak 4 orang (20\%), tergolong sedang sebanyak 15 orang (75\%) dan yang tergolong rendah sebanyak 1 orang (5\%) atau pada kategori sedang yakni sebanyak 15 orang siswa (75\%) dari 20 siswa.

2. Kemampuan membaca al-Qur'an siswa kelas $X^{4}$ Madarasah Aliyah Raudhatul Ulum setelah mengikuti dauroh al-Qur'an yang tergolong tinggi sebanyak 8 orang $(20 \%)$, tergolong sedang sebanyak 17 orang $(75 \%)$ dan yang tergolong rendah sebanyak 5 orang $(5 \%)$, atau pada kategori tinggi yakni sebanyak 8 orang siswa (40\%) dari 20 siswa.

3. Perbedaan kemampuan membaca al-Qur'an siswa Kelas $X^{4}$ Madarasah Aliyah Raudhatul Ulum Sakatiga Indralaya sebelum dan setelah mengikuti dauroh alQur'an dengan diambil df 40 diperoleh tabel pada taraf signifikansi $5 \%=2,42$ dan ada taraf signifikansi $1 \%=2,02$. Karena " $t_{0}$ " $=6,156$ lebih besar dari $t_{t}$, maka hipotesis nihil ditolak dan hipotesis alternatife diterima yaitu ada perbedaan signifikan antara kemampuan membaca kelas $X^{4}$ MA Raudhatul Ulum sebelum dan setelah mengikuti dauroh al-Qur'an. Dapat disimpulkan bahwa mengajar dengan menggunakan metode dauroh al-Qur'an memberikan peningkatan yang signifikan terhadap kemampuan membaca al-Qur'an siswa kelas $X^{4}$ MA Raudhatul Ulum Sakatiga. 
RAUDHAH Proud To Be Professionals gurnal Tarbiyakndamiyak

Volume 4 Nomor 1 Edisi Juni 2019

P-ISSN : 2541-3686

\section{DAFTAR PUSTAKA}

Ahmad Munjin Nasih,dkk. 2009. Metode Dan Teknik Pemebelajaran Pendidikan Agama Islam. Bandung : PT Refika Aditama.

Ahmad, Abu. 2006. MetodeKhususPendidikanAgama Islam. Bandung:CV.Amrico

Ancok, Djamaludin.2009. Validitas dan Reliabilitas Instrumen Penelitian (Edisis Revisi). Jakarta: LP3ES

Aravik, Havis, 2018. Pengantar Studi Islam, Palembang: Rafah Press.

Arikunto, Suharsimi.2010.Manajemen Penelitian. Jakarta: Rineka Cipta

Arikunto, Suharsimi.2014.Prosedur Penelitian Suatu Pendekatan. Jakarta: Rineka Cipta

Atabik Ali, A. Zuhdi Muhdlor.2003.Kamus Kontemporer Aran Indonesia. Yogyakarta: Multi Karya Grafika.

Departemen Pendidikan Nasional. 2013. Kamus Besar Bahasa Indonesia, edisi keempat, (Jakarta: PT Gramedia Pustaka Utama

Djaali.2013. Psikologi Pendidikan, cet.ke-7. Jakarta: Bumi Aksara.

Djunaidi Ghony dan Fauzan Almanshur.2012.Metodelogi Penelitian Kualitatif. Jogjakarta: Ar-Ruzz Media

Emzir.2014. Metodologi Penelitian Pendidikan (Kuantitatif dan Kualitatif). Jakarta: Rajawali Pers

Harjanto.2005.Perencanaan Pengajaran. Jakarta: Rineka Cipta

Harto, Kasinyo.2012.Desain Pembelajaran Agama Islam, (Jakarta: PT Raja Grafindo Persada

Hujair AH, Sanaky.2003. Pradigma Pendidikan Islam: Membangun Masyarakat Madani Indonesia. Yogyakarta : Safiria Insania Press

Majid, Abdul.2014.Belajar dan Pembelajaran (Pendidikan Agama Islam), cet. Ke-II,. Bandung: Remaja Rosdakarya

Manna'Khalil al-Qattan, Mabahits fi' ulumil al-Qur'an, (Riyadl: Mansyurat al-'ashri alhadits)

Marihot Tua dan Efendi Hariandja.2002.Manajemen Sumber Daya Manusia. PT Grasindo: Jakarta

Masyuri dan M. Zainuddin.2011.Metodologi Penelitian (Pendekatan, Praktek dan Aplikatif), Bandung: PT. Refika Aditama 
Penerapan Dauroh Al-Qur'an Bagi Siswi Kelas X di Madrasah Aliyah Raudhatul Ulum

Sakatiga Indralaya

Komputri Apria Santi

Muhaimin dan AbdulMujib. 2003. PemikiranPendidikanIslam.

Bandung:TrigendaKarya

Nurgiyantoro, dkk.2002.Statistik Terapan: Untuk Penelitian Ilmu-Ilmu Sosial. Yogyakarta: Gajah Mada University Press

Nurkaranca, Wayan.2002.Evaluasi Hasil Belajar. Surabaya Indonesia Usaha Nasional

Omar, Hamalik.2011.Perencanaan Pengajaran Berdasarkan Pendekatan Sistem. Jakarta:

Bumi Aksara

Pasal 1 (Ayat 1 dan 4), Undang-undang dan Peraturan Pemerintah Tentang Pendidikan, (Depag RI: 2006)

Ramayulis.2010.Metodologi Pendidikan Agama Islam. Jakarta: Kalam Mulia

Roestiyah.2006.Masalah-Masalah Ilmu Keguruan. Jakarta : Bumi Aksara

Rohita.2010.Manajemen Sekolah (Teori Dasar dan Praktik), cetakan ketiga. Bandung: PT Refika Aditama

Saebani, Beni Ahmad.2008. Metode Penelitian. Bandung: Pustaka Setia

Santoso, Budi.2010.Skema dan Mekanisme Pelatihan, (Panduan Penyelenggaraan Pelatihan). Jakarta: Terangi

Sudijono, Anas.2008.Pengantar Statisti Pendidikan. Jakarta: PT. Raja Grafindo Persada

Sudjana, Nana.2001. Dasar-DasarProsesBelajarMengajar. Bandung:SinarBaru

Sugiyono.2013.Metode Penelitian Kuantitaif, Kualitatif dan RED. Bandung : ALFABETA

Suprijono, Agus.2014.Cooperative Learning (Teori dan Aplikasi Paikem). Yohyakarta: Pustaka Pelajar

Surakhmad, Winarno. 2004. PengantarInteraksiBelajarMengajar. Bandung:Tarsito

Sutisna. Oteng.2008.Administrasi Pendidikan Dasar Teoritis Untuk Praktek Profesional. Bandung : Angkasa

SyaifulBahriDjamarahdanAswanZain. 2006. StrategiBelajarMengajar. Jakarta:Rineka Cipta

Udin S winataputra,at-al. 2010.Belajar dan Pembelajaran. Dirjen Pembinaan Kelembagaan Agama Islam danUniversitas Terbuka

Undang-undang SISDIKNAS (UU RI No. 20 Th. 2003). Jakarta: Sinar Grafika. 2011

Zakiah Daradjat,dkk.2011. Pengajaran Agama Islam. Jakarta: Bumi Aksara

Zuhairini,dkk. 2006 Metodik Khusus Pendidikan Agama. Surbaya: Biro Ilmiah Fakultas Tarbiyah IAIN Sunan Ampel Malang 